\title{
Cost benefit ratio of bio-control agents, botanicals and fungicide in the management of white rot of onion caused by Sclerotium rolfsii Sacc. in Manipur
}

\section{Rimamay Konjengbam \& Rajkumari Tombisana Devi}

Journal of Agriculture and Ecology

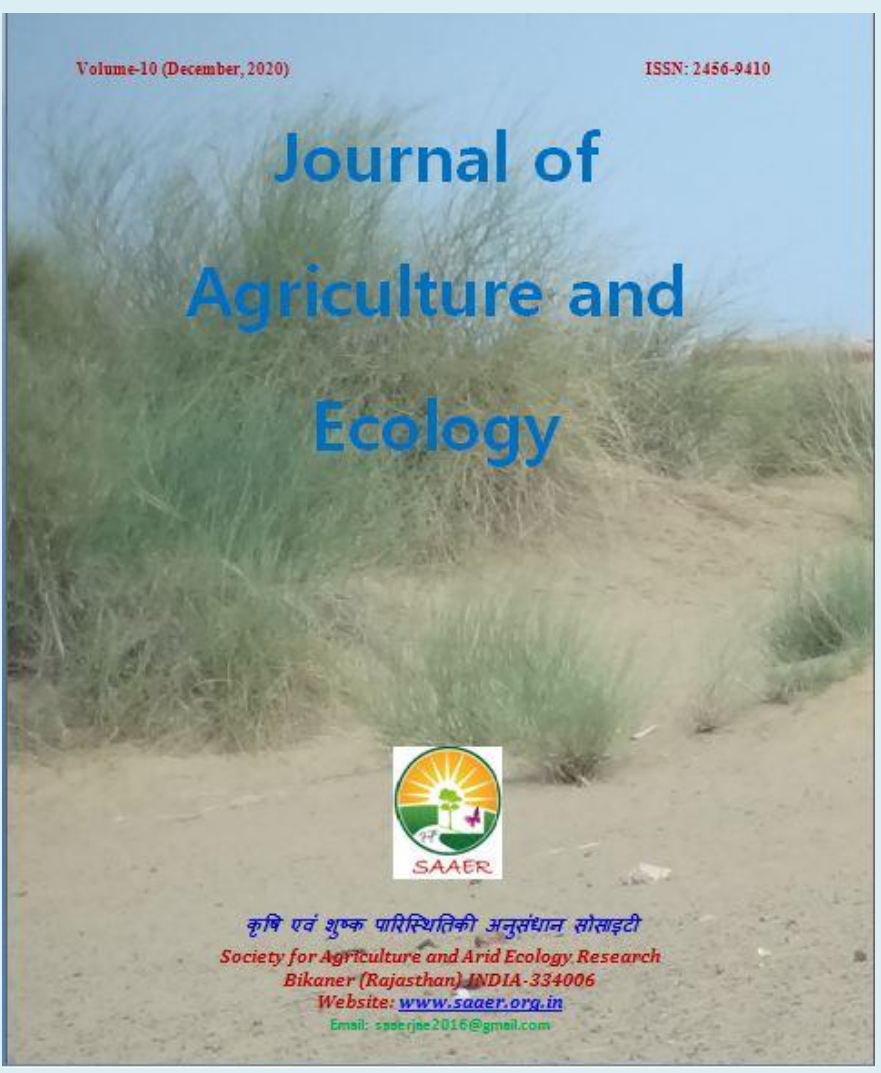

ISSN: 2456-9410

Volume: 10

Journal of Agriculture and Ecology (2020) 10: 83-89 http://doi.org/10.53911/JAE.2020.10208

कृषि एवं शुष्क पारिस्थितिकी अनुसंधान सोसाइटी

Bikaner (Rajasthan) JNDIA-334006
Website: www.saaer.org.in 
Cost benefit ratio of bio-control agents, botanicals and fungicide in the management of white rot of onion caused by Sclerotium rolfsii Sacc. in

\title{
Manipur
}

\author{
Rimamay Konjengbam ${ }^{1} \searrow \&$ Rajkumari Tombisana Devi ${ }^{2}$ \\ ${ }^{I}$ Department of Plant Pathology, College of Agriculture, Central Agricultural University, Iroishemba, \\ Imphal West-795004, Manipur, India \\ ${ }^{2}$ Department of Plant Pathology, College of Post Graduate Studies in Agricultural Sciences, Central \\ Agricultural University, Umiam, Barapani-793104, Meghalaya, India \\ $\square$ Corresponding author: R. Konjengbam, E-mail: rimamay24@gmail.com
}

\section{Article Info}

Article history

Received: 30 October 2020

Accepted: 20 December 2020

Available online: 31 December 2020

Key Words: Onion, white rot, Sclerotium rolfsii, biocontrol agents, botanicals, fungicide.

\begin{abstract}
The research investigation was undertaken to evaluate the economics of the management of white rot of onion by Trichoderma harzianum, Trichoderma viride, garlic (Allium sativum L.), turmeric (Cucurma longa L.), sweet flag (Acorus calamus L.) and Carbendazim (50\% WP). Carbendazim recorded highest gross return followed by $T$. harzianum and $T$. viride respectively. Carbendazim also recorded highest net return followed by $T$. harzianum and garlic respectively. Among the treatments, Carbendazim gave the highest net return cost benefit ratio of 1:3.25. Garlic extract gave cost benefit ratio of 1:2.96. T. harzianum gave cost benefit ratio of 1:2.89.
\end{abstract}

Copyright (C) Konjengbam \& Devi, This is an open access article published under the terms of the Creative Commons Attribution License, which permits unrestricted use, distribution, and reproduction in any medium, provided the original work is properly cited.

Preferred citation: Konjengbam R \& Devi RT. 2020. Cost benefit ratio of bio-control agents, botanicals and fungicide in the management of white rot of onion caused by Sclerotium rolfsii Sacc. in Manipur. Journal of Agriculture and Ecology, 10: 83-89; http://doi.org/10.53911/JAE.2020.10208.

\section{Introduction}

Onion (Allium cepa L.) is a vegetable and spice crop of economic importance in Manipur. It was originated in Central Asia (Vavilov 1951). It is included under the family Amaryllidaceae. It is also used as medicines since it is rich in antioxidant enzymes and antimicrobial compounds (Stajner \& Varga 2003; Santas et al. 2010). Onion is often used in the preparation of cuisine including salad, gravy, sauce, pickles, curry, chutney and many more. Onion contains organic disulphides including allyl propyl disulphides, methyl cis-propenyl disulphides, methy transpropenyl disulphides, cis-propenyl propyl disulphides, trans- propenyl propyl disulphides, methyl propenyl trisulphides and propenyl propyl trisulphides (Brodnitz et al. 1969; Augusti \& Benaim 1975). The varying colour of onion skin is due to anthocyanin and flavonol like quercetin glucoside (Downes et al. 2009). It is being referred to as queen of the kitchen (Selvaraj 1976). In Manipur, bulb onion is mostly cultivated as a cool season 
crop. Onion suffers from numerous diseases and white rot of onion caused by Sclerotium rolfsii Sacc. is one of important diseases which reduces onion production to a significant extent. The disease is characterized by yellowing of leaves from tips which extend downwards and is subsequently accompanied by blighting, drooping and wilting of aerial part of the plant. Infected bulbs are soft, watery, decayed and white fluffy mycelium with small circular white, brown to black colour sclerotia of the fungus are present on the infected bulb scales and basal plate and roots. The fungus have a very large host range of about 500 plant species and attack both monocots and dicots (Aycock 1966; Punja 1985). The fungus produced sclerotia which remains viable for long period (Punja 1985). The fungus survives as sclerotia, hymenial layers, and also as mycelium in infected plants, plant debris and on dead organic materials (Mullen 2001). Sclerotia are differentiated into thick walled rind cells which are rich in melanin pigment, thinner walled cortex and extremely thick walled medulla which are full of reserve materials and this arrangement in turn make sclerotia resistance to biological degradation (Chet et al. 1969). There are variability among isolates of $S$. rolfsii obtained from different hosts and locations (Sarma et al. 2002). Therefore, the utilization of eco-friendly biocontrol agents and botanicals are essential as the continuous use of fungicides are harmful to human health, environment, confers phytotoxic effect, non target effect on unrelated microorganism and development of resistance of the pathogen against fungicides (Franke et al. 1998; Dias 2012; Nettles et al. 2016). However, the use of fungicides is also essential as it cost less compared to biocontrol agents and botanicals. Moreover, fungicides are often considered as the last line of defence in integrated disease management practices that protect an inherent yield potential ( Poole and Arnaudin 2014). Hence, the present study was conducted to evaluate the cost benefit ratio of the management of white rot of onion caused by Sclerotium rolfsii Sacc. by biocontrol agents namely, Trichoderma harzianum and Trichoderma viride and aqueous extract (1:1 $w / v)$ of botanicals namely, clove of garlic (Allium sativum L.), rhizome of turmeric (Cucurma longa L.) and rhizome of sweet flag (Acorus calamus L.) and fungicide namely, Carbendazim (50\% WP) in Manipur as it was crucial to evaluate the economic for sustainable management of this disease.

\section{Materials and Methods}

\section{Collection, identification and maintenance of the pathogen}

The diseased onion bulbs which were cultivated in the experimental site in the previous crop season were collected. The infected bulb scales were cut into small pieces and were surface sterilised with $1 \%$ sodium hypochloride solution. The sterilised pieces were blot dried and inoculated on potato dextrose agar and were incubated at $28 \pm 1{ }^{\circ} \mathrm{C}$ for 4 days. The pathogen was purified by hyphal tip cut method and re-isolated on PDA and identified by comparison with relevant monographs.

\section{Application of treatment}

Seedlings dipping and sprayings at the base of the onion plants were adopted for each treatment. Onion seedlings were dipped in suspension of each treatment of both 
Trichoderma harzianum and T. viride $(10 \mathrm{~g} / \mathrm{L})$, garlic $(3 \mathrm{~mL} / \mathrm{L})$, turmeric $(10 \mathrm{~mL} / \mathrm{L})$, sweet flag $(10 \mathrm{~mL} / \mathrm{L})$, and carbendazim $(1 \mathrm{~g} / \mathrm{L})$. Basal spraying at the base of onion plants were given thrice after one month of transplanting at 30 days intervals by suspension of all the treatments at the same concentrations used for seedlings dipping. Control plots were not subjected to treatment. Three replications were adopted for each treatment.

\section{Assessment of economics}

The research investigation was conducted at College of Agriculture, Central Agricultural University, Imphal, India during 2015-2016. Imphal have a sub-tropical climate. The soil of experimental site is clayey in texture and acidic in reaction ranging from $\mathrm{p}^{\mathrm{H} 5.6}$ to $\mathrm{p}^{\mathrm{H}}$ 5.8. The experiment was carried out in rabi season using randomized block design (RBD) with three replications. The plot measures $2 \mathrm{~m} \mathrm{X} 1.5 \mathrm{~m}$ and a spacing of $10 \mathrm{~cm} \mathrm{X}$ $10 \mathrm{~cm}$ was adopted. There were a total of 266 plants on a single plot. Nasik Red N-53 was used for the investigation. Economics of individual treatment were worked out using the following indices:

\section{Cost of cultivation}

It was calculated by taking into account the inputs, labour and operational costs.

\section{Gross return}

The total monetary values of the economic produce, which in this investigation is fresh onion bulb obtained was calculated based on the price of local market and is expressed on unit area basis.

\section{Net return}

It is also referred to as net profit. It was calculated by subtracting the total cost of cultivation for the various treatments from their respective gross returns.

\section{Cost benefit ratio (Return per rupee invested)}

It is also referred to as input-output ratio and cost benefit ratio. It was calculated by using the formula

Cost benefit ratio $=\frac{\text { Gross return }}{\text { Total cost of cultivation }}$

This index provides an estimate of the benefit, derived from the expenditure incurred in adopting a particular system.

\section{Results and Discussion}

The fungus was identified as Sclerotium rolfsii Saccardo based on morphological characteristics and taxonomic keys available in the literatures (Saccardo 1913; Mordue 1974; Punja 1985). Carbendazim gave highest bulb yield of 191.2 q/ha.

\section{Cost of Cultivation}

The total capital investments in the production of onion bulb with different treatments are presented in Table 1 and Table 2. The maximum capital investments of $\square 1,53,400 /$ ha was needed for Trichoderma harzianum and $T$. viride for the management of white rot of onion. While minimum capital investment of $\square 1,47,000 /$ ha was needed in plots sprayed with Carbendazim.

\section{Gross Return}

Gross return presented in Table 3 showed that maximum gross income of Rs. $4,78,000 /$ ha was recorded from plot sprayed with Carbendazim which was followed by $T$. harzianum recording $\square 4,44,750 / \mathrm{ha}$. The lowest gross income of Rs. 4,09,250/ha was obtained from plots sprayed with sweet flag extract. 


\section{Net Return}

Data presented in Table 3 revealed that among the different treatments, maximum net income of Rs. 3,31,000/ha was recorded from plot sprayed with Carbendazim, and was followed by garlic extract which gave net return of Rs. 2,89,850/ha. However, the lowest net income of Rs. 2,59,250/ha was obtained from the plots sprayed with sweet flag extract.

\section{Cost benefit ratio (Return per rupee invested)}

Data presented in Table 3 revealed that the maximum cost benefit ratio of 1:3.25 was recorded with Carbendazim followed by cost benefit ratio of 1:2.96 with garlic extract. Trichoderma harzianum and $T$. viride gave cost benefit ratio of 1:2.89 and 1:2.86. Least cost benefit ratio was observed from the plots sprayed with sweet flag extract (1:2.72). The present findings are in conformity with that of Raut and Patil (2005) who reported that the cost benefit ratio of 1:2.15 was highest in plots treated with $1 \%$ Bavistin (Carbendazim), followed by $T$. viride (1:1.47), $0.1 \%$ garlic extract (1:1.38) in management of foot rot and wilt of tomato caused by Fusarium oxysporum and Rhizoctonia bataticola. Jadav et al. (2016) reported that application of Trichoderma species for the management of stem rot of groundnut caused by $S$. rolfsii gave an average cost benefit ratio of $1: 1.89$. Similarly, Laksman et al. (2018) stated that treatment of sunflower wilt caused by $S$. rolfsii with $T$. viride during 2014-15 and 2015-16 gave benefit cost ratio of 1.23 and 1.28 respectively while treatment with $T$. harzianum during 2014-15 and 2015-16 gave benefit cost ratio of 1.26 and 1.31 respectively. Siddique et al. 2018 reported that highest benefit cost ratio of 1.89 was obtained from Carbendazim in the management of foot and root rot of brinjal caused by $S$. rolfsii and treatment with $T$. harzianum gave a benefit cost ratio of 1.34 respectively. Daunde et al. (2020) also reported that Carbendazim (50WP), $T$. harzianum and $T$. viride gave a cost benefit ratio of $1: 2.79,1: 2.38$ and $1: 2.32$ in the management of collar rot of chilli caused by $S$. rolfsii. The present findings are also in conformity with the findings of Sunkad (2012) and Jadon et al. (2017).

Table 1. Cost of cultivation of onion ( Nasik Red N-53) per hectare

\begin{tabular}{|c|c|c|c|c|}
\hline $\begin{array}{c}\text { Serial } \\
\text { number }\end{array}$ & Particulars & Quantity/unit & Rate(Rs) & Total(Rs) \\
\hline \multirow[t]{3}{*}{1.} & Land preparation & & & \\
\hline & a) Tractor & $5 \mathrm{hrs}$ & $500 / \mathrm{hr}$ & 2500 \\
\hline & b) Power tiller & 6hrs & $700 / \mathrm{hr}$ & 4200 \\
\hline 2 & Seed $(12 \mathrm{Kg} / \mathrm{ha})$ & $12 \mathrm{~kg}$ & $1100 / \mathrm{kg}$ & 13200 \\
\hline \multirow[t]{4}{*}{3} & Fertilizer & & & \\
\hline & a) Urea $(125 \mathrm{~kg} / \mathrm{ha})$ & $125 \mathrm{~kg}$ & $11 / \mathrm{kg}$ & 1375 \\
\hline & b) SSP (60kg/ha) & $60 \mathrm{~kg}$ & $15 / \mathrm{kg}$ & 900 \\
\hline & c) $\mathrm{MOP}(100 \mathrm{~kg} / \mathrm{ha})$ & $100 \mathrm{~kg}$ & $28 / \mathrm{kg}$ & 2800 \\
\hline
\end{tabular}




\begin{tabular}{|c|c|c|c|c|c|c|c|}
\hline 4 & \multicolumn{3}{|c|}{ FYM (20t/ha) } & $20,000 \mathrm{~kg}$ & \multicolumn{2}{|c|}{$5 / \mathrm{kg}$} & $1,00,000$ \\
\hline \multirow[t]{9}{*}{5} & \multicolumn{7}{|c|}{ Labour cost } \\
\hline & \multicolumn{3}{|c|}{ a) Nursery bed preparation } & 2 men/day & \multicolumn{2}{|c|}{ 225/man/day } & 450 \\
\hline & \multicolumn{3}{|c|}{ b) Levelling } & 15 men/day & \multicolumn{2}{|c|}{ 225/man/day } & 3375 \\
\hline & \multicolumn{3}{|c|}{ c) Seed sowing } & $1 \mathrm{men} / \mathrm{day}$ & \multicolumn{2}{|c|}{$225 / \mathrm{man} /$ day } & 225 \\
\hline & \multicolumn{3}{|c|}{ d) Transplanting } & 20 men/day & \multicolumn{2}{|c|}{ 225/man/day } & 4500 \\
\hline & \multicolumn{3}{|c|}{ e) Gap feeling } & $3 \mathrm{men} / \mathrm{day}$ & \multicolumn{2}{|c|}{$225 / \mathrm{man} /$ day } & 675 \\
\hline & \multicolumn{3}{|c|}{ f) Intercultural operation } & 20 men/day & \multicolumn{2}{|c|}{ 225/man/day } & 4500 \\
\hline & \multicolumn{3}{|c|}{ g) Irrigation } & $8 \mathrm{men} / \mathrm{day}$ & \multicolumn{2}{|c|}{ 225/man/day } & 1800 \\
\hline & \multicolumn{3}{|c|}{ h) Harvesting and handling } & $20 \mathrm{men} /$ day & \multicolumn{2}{|c|}{ 225/man/day } & 4500 \\
\hline $\begin{array}{c}\text { Total A } \\
(\mathbf{R s})\end{array}$ & & & & & & & $1,45,000$ \\
\hline \multicolumn{8}{|c|}{ Table 2. Cost of cultivation for each treatment } \\
\hline Treatr & & Quantity/ha & $\begin{array}{c}\text { Rate of } \\
\text { treatment } \\
(\mathrm{Rs} / \mathrm{kg})\end{array}$ & $\begin{array}{c}\text { Total cost } \\
\text { of } \\
\text { treatment } \\
\text { (a) } \\
\text { (Rs/ha) }\end{array}$ & $\begin{array}{c}\text { Total } \\
\text { number of } \\
\text { application } \\
\text { (b) }\end{array}$ & $\begin{array}{c}\text { Total } \\
\text { B } \\
(\mathbf{a} \text { X b }) \\
(\mathbf{R s})\end{array}$ & $\begin{array}{c}\text { Total cost } \\
\text { of } \\
\text { cultivation } \\
\text { A+B (Rs) }\end{array}$ \\
\hline $\begin{array}{r}\text { Trichoa } \\
\text { harzia }\end{array}$ & ma & $2.1 \mathrm{~kg} / \mathrm{ha}$ & 1000 & 2100 & 4 & 8400 & $1,53,400$ \\
\hline T. vir & & $2.1 \mathrm{~kg} / \mathrm{ha}$ & 1000 & 2100 & 4 & 8400 & $1,53,400$ \\
\hline Garl & & $5 \mathrm{~kg} / \mathrm{ha}$ & 120 & 600 & 4 & 2400 & $1,47,400$ \\
\hline Turm & & $50 \mathrm{~kg} / \mathrm{ha}$ & 30 & 1500 & 4 & 6000 & $1,51,000$ \\
\hline Acor & & $50 \mathrm{~kg} / \mathrm{ha}$ & 25 & 1250 & 4 & 5000 & $1,50,000$ \\
\hline Carbenc & $\mathrm{zim}$ & $1 \mathrm{~kg} / \mathrm{ha}$ & 500 & 500 & 4 & 2000 & $1,47,000$ \\
\hline
\end{tabular}

Table 3. Effect of bio control agents, botanicals and fungicide on bulb yield, gross return, net return and cost benefit ratio

\begin{tabular}{cccccc}
\hline Treatment & $\begin{array}{c}\text { Yield } \\
\text { (quintal/ } \\
\text { ha) }\end{array}$ & $\begin{array}{c}\text { Gross } \\
\text { return } \\
\text { @ } \mathbf{~ R s} \\
\mathbf{2 5 / \mathbf { k g }}\end{array}$ & $\begin{array}{c}\text { Total cost of } \\
\text { cultivation (Rs/ha) } \\
\mathbf{( R s / h a )}\end{array}$ & $\begin{array}{c}\text { Net } \\
\text { return } \\
\text { Rs/ha }\end{array}$ & $\begin{array}{c}\text { Cost benefit } \\
\text { ratio }\end{array}$ \\
\hline $\begin{array}{c}\text { Trichoderma } \\
\text { harzianum }\end{array}$ & 177.9 & $4,44,750$ & $1,53,400$ & $2,91,350$ & $1: 2.89$ \\
T. viride & 175.6 & $4,39,000$ & $1,53,400$ & $2,85,600$ & $1: 2.86$ \\
Garlic & 174.9 & $4,37,250$ & $1,47,400$ & $2,89,850$ & $1: 2.96$
\end{tabular}




Turmeric
Sweet flag 166.6
Carbendazim $163.7 \quad 4,09,500$
Control
Conclusion
Utilization of fungicide in the
management of white rot of onion gave a
highest net return and cost benefit ratio.
However, the constant use of fungicide is
disastrous to environment and living organisms.
Therefore, alternatives for fungicides such as
biocontrol agents and locally available
botanicals should also be considered although it
is not as beneficial in terms of economics.
Fungicide can be employed in integrated disease
management strategies so as to raise the net
return and cost benefit of the crop productivity.
Biocontrol agents and botanicals can be
employed in organic farming and can also be
utilized in integrated disease management
alongside with fungicide. Hence, consideration
of not only cost benefit ratio of the crop's
production but also that of environment and its
biodiversity is very crucial.
Acknowedgement

\section{Acknowledgement}

I would like to convey deep gratitude to my late mother Nongmaithem Madhuri Devi for her constant support, guidance and patience while conducting this research.

\section{References}

Augusti KT \& Benaim ME. 1975. Effect of essential oil of onion (allyl propyl disulphide) on blood glucose, free fatty acid and insulin levels of normal subjects. Clinica Chimica Acta, 60 (1): 121-123.
$1,51,000 \quad 2,65,500 \quad 1: 2.75$

$1,50,000 \quad 2,59,250 \quad 1: 2.72$

$1,47,000 \quad 3,31,000 \quad 1: 3.25$

$1,45,000 \quad 1,81,000 \quad 1: 2.25$

Aycock R. 1966. Stem rot and other diseases caused by Sclerotium rolfsii. NC State University Technology Bulletin, 174: 202.

Brodnitz MH, Pollock CL \& Vallon PP. 1969.

Flavour components of onion oil.

Journal of Agriculture and Food Chemistry, 17 (4): 760-763.

Chet I, Henis Y \& Kislev N. 1969. Ultrastructure of sclerotia and hyphae of Sclerotium rolfsii Sacc. Journal of General Microbiology, 57(2): 541-546.

Daunde AT, Apet KT, Navgire KD \& Khandare VS. 2020. Integrated Management of Collar Rot of Chilli Caused by Sclerotium rolfsii Sacc. International Journal of Current Microbiology \& Applies Sciences, 9 (6): 2187-2194.

Downes K, Chope GA \&Terry LA. Effect of curing at different temperatures on biochemical composition of onion (Allium cepa L.) skin from three freshly cured and cold stored UK- grown onion cultivars. Post Harvest Biology \& Technology, 54 (2): 80-86.

Franke MD, Brenneman TB, Stevenson KL \& Padgett GB. 1998. Sensitivity of Isolates of Sclerotium rolfsii from Peanut in Georgia to Selected Fungicides. Plant Disease, 8 (5): 578-583.

Jadav NB, Undhad SV, Bariya MK \& Parakhia AM. 2016. Economic impact of frontline 
demonstration of Trichoderma against stem rot (Sclerotium rolfsii) in kharif groundnut. International Journal of Agricultural Sciences, 8 (26): 1527-1528. Jadon KS, Thirumalaisamy PP, Padavi RD \& Koradia VG. 2017. Biological control of Sclerotium rolfsii and infection Aspergillus flavus on peanut with combining Trichoderma harzianum and Pseudomonas fluorescens in the field. Journal of Plant Pathology, 47 (2): 7989.

Lakshman SS, Chander RS \& Godke MK. 2018. An Approach to Integrated Management of Sunflower Wilt through Bio-Inoculants. European Journal of Experimental Biology, 8 (5): 31.

Mullen J. 2001. Southern blight, Southern stem blight, White mold. The Plant Health Instructor, https://doi.org/10.1094/PHI-I2001-0104-01.

Mordue JEM. 1974. Sclerotium rolfsii. CMI descriptions of pathogenic fungi and bacteria. Commonwealth Mycological Institute, Kew, Surrey, England, No. 410.

Nettles R, Watkins J, Ricks K, Boyer M, Licht M, Atwood LW, People M, Smith RG, Mortensen DA \& Koide RT. 2016. Influence of pesticide seed treatments on rhizosphere fungal and bacterial communities and leaf fungal endophyte communities in maize and soybean. Applied Soil Ecology, 102: 6169.

Poole NF \& Arnaudin ME. 2014. The role of fungicides for effective disease management in cereal crops. Canadian Journal of Plant Pathology, 36(1):1- 11.doi:10.1080/ $070 \quad 606 \quad 61$. 2013.870230 .

Punja ZK. 1985. The biology, ecology, and control of Sclerotium rolfsii. Annual Review of Phytopathology, 23: 97-127.

Saccardo PA. 1913. Sclerotium rolfsii. Sylloge Fungorum XXII. Pavia, Italy, 1500 pp.

Sarma BK, Singh UP \& Singh KP .2002. Variability in Indian isolates of Sclerotium rolfsii. Mycologia, 94 (6): 1051-1058.

Santas J, Almajano MP \& Carbo R 2010. Antimicrobial and antioxidant activity of crude onion (Allium cepa L.) extracts. International Journal of Food Science \& Technology, 45 (2): 403-409.

Selvaraj S. 1976. Onion is queen of kitchen. Kishan World, 3 (12): 32-34.

Siddique NA, Ahmmed ANF, Jahan N, Mazumder MGH \& Islam R. 2018. Management of Foot and Root Rot Disease of Eggplant (Solanum melongena L.) caused by Sclerotium rolfsii under In Vivo Condition. The Agriculturists, 16 (1): 78-86.

Stajner D \& Varga IS. 2003. An evaluation of antioxidant abilities of Allium species. Acta Biologica Szegediensis, 47 (1): 103-106.

Sunkad G. 2012. Tebuconazole: A new triazole fungicide molecule for the management of groundnut caused by Sclerotium rolfsii. The Bioscan, 7 (4): 601-603.

Vavilov NI. 1951. The origin, variation, immunity and breeding of cultivated plants. Chronica Botanica Waltham, Mass, USA, pp 1-366. 